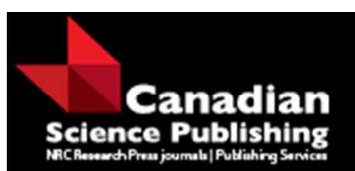

Canadian Journal of Forest Research Revue canadienne de recherche forestière

\title{
Development and evaluation of a biomass increment-based index for site productivity
}

\begin{tabular}{|r|l|}
\hline Journal: & Canadian Journal of Forest Research \\
\hline Manuscript ID & cjfr-2016-0330.R1 \\
\hline Manuscript Type: & Article \\
\hline Date Submitted by the Author: & 12-Nov-2016 \\
\hline Complete List of Authors: & $\begin{array}{l}\text { Hennigar, Chris; University of New Brunswick, Faculty of Forestry and } \\
\text { Environmental Management } \\
\text { Weiskittel, Aaron; University of Maine } \\
\text { Allen, Howard; ProFOR Consulting } \\
\text { MacLean, David; University of New Brunswick, }\end{array}$ \\
\hline Keyword: & site index, biomass growth, mixed species, productivity, Acadian forest \\
\hline & \multicolumn{2}{|c}{} \\
\hline
\end{tabular}

SCHOLARONE
Manuscripts

Manuscripts 


\section{Development and evaluation of a biomass increment-based index for site}

\section{2 productivity}

3

4 Chris Hennigar (corresponding author; 506-470-3373; chris.hennigar@unb.ca) $)^{1}$, Aaron

5 Weiskittel (aaron.weiskittel@maine.edu $)^{2}$, H. Lee Allen (allen.profor@gmail.com) ${ }^{3}$, and

6 David A. MacLean (macleand@unb.ca) ${ }^{1}$

7

$8{ }^{1}$ University of New Brunswick, Faculty of Forestry and Environmental Management, P.O. Box

94400 , Fredericton, NB, E3B 5A3 Canada

$10 \quad{ }^{2}$ University of Maine, School of Forest Resources, Orono, ME, USA

$11{ }^{3}$ ProFOR Consulting, 225 Winding Ridge Dr., Cary, NC, USA 


\section{Abstract}

13 Measures of forest productivity generally rely on site index, which can be problematic for multi-

14 cohort and mixed-species stands. Using stand growth and dominant tree height-age (i.e., site

15 tree) measurements from $~ 10,900$ plot locations from Maine, Nova Scotia, New Brunswick, and

16 Prince Edward Island, a forest productivity model for the Acadian Region was developed as a

17 function of climate, lithology, soils, and topographic metrics. Approximately $65 \%$ of variation in

18 observed above-ground dry-biomass growth rate (BG) was explained by a Chapman-Richards

19 function of temperature, bedrock, soil root space, slope, and depth to water in combination with

20 stand structure and species predictors. Productivity was then defined in terms of the predicted

21 asymptote of BG, holding structure and species constant, which was termed biomass growth

22 index (BGI); i.e., the site-influenced component of the BG relationship. BGI was mapped on a

$2320 \mathrm{~m}$ grid throughout the region. BGI explained $0-30 \%$ of the variability in spruce (Picea sp.)

24 and balsam fir (Abies balsamea) site index, and had similar site index predictive performance $( \pm$

$255 \%$ ) when compared to existing land productivity classifications in each province. BGI provides

26 a direct relationship between site variables and growth and can help guide forest management

27 decisions and future research.

28

29 Keywords: Productivity, mixed species, site index, Acadian forest, biomass growth 


\section{Introduction}

Determining site productivity is an important yet difficult issue for forest management and planning (e.g., Carmean 1975; Skovsgaard and Vanclay 2008, 2013). A variety of direct and indirect as well as phytocentric and geocentric measures of site productivity have been used in the past. The most common site productivity measure used today is site index, which has numerous advantages and disadvantages (Weiskittel et al. 2011b). The most important advantages of site index are a long history of development and use, as well as high interpretability; while key disadvantages are that it requires direct expensive measurements and existing equations, tree social status is not always fixed over time (Raulier et al. 2003), and can be sensitive to stand age (Fig. 3.1 in Weiskittel et al. 2011b; Fig. 3 in Goelz and Burk 1992). In particular, site index can be difficult to estimate and use in mixed-species and multi-cohort stands, especially with long histories of partial harvesting regimes.

In mixed-species and uneven-aged stand types, a variety of approaches have been used to determine and quantify site productivity. The most common include: (1) a modified estimate of site index (e.g., Curtis and Post 1964; Hamel et al. 2004); (2) ecological-based classifications (e.g., Monserud 1984; Wang 1998); and (3) increment-based indices (e.g., Schmoldt et al. 1985; Vanclay 1989). Like site index, these various approaches have important advantages and disadvantages, which may limit their application. For example, a composite site index for mixed species requires the construction of conversion equations (e.g., Carmean 1979; Nigh 1995), while ecological-based classifications are categorical, making additional analysis difficult and are often too coarse for management planning. Increment-based indices have been conducted at the individual tree-level using either diameter (Vanclay 1989) or height (Stage 1963), as well as with stand-level variables (e.g., Schmoldt et al. 1985; Berrill and O'Hara 2014). Although the increment-based approach offers several advantages, it generally requires permanent plots, which 
54 may limit its robustness and applicability when those are not available. In addition, most of these 55 methods are focused on the stand-level productivity and can make it hard to compare across 56 broad geographic regions. Recent work has related observed site indices to climate (Weiskittel et al. 2011a), soils (Jiang et al. 2015), and modeled or observed net primary production (Swenson et al. 2005), which allows site index to be mapped across a region (e.g., Coops et al. 2011). However, mapping of increment-based measures of productivity has received less attention. The Acadian Region is a transitional forest with a relatively large number of tree species present and complex stand structures due to past management and an abundance of natural regeneration. Consequently, there is a long history of site productivity studies in this region going back more than 50 years (AAFC 1998). However, previous efforts have largely focused on unmanaged spruce-fir (Picea-Abies) site index (Griffin and Johnson 1980; Vicary et al. 1984; Ker and Bowling 1991; Williams et al. 1991; Steinman 1992) and ecological land classification (MacDougall et al. 1988; Solomon et al. 1995; Zelazny et al. 2007; Keys et al. 2010). Studies have identified several climate (Briggs and Lemin 1992) and soil properties related to productivity such as drainage class and soil depth (Briggs 1994; Steinman 1992). However, a consistent, high-resolution, and robust measure of site productivity does not exist for the region. In addition, the tremendous increase in availability of high resolution and spatially explicit

71 information including elevation, climate, lithology, soils, hydrology, and vegetative cover data offers an opportunity to examine a greater array of influential factors on productivity in this 73 region.

The overall goal of this analysis was to develop a quantitative, species-independent, and unified site productivity model that could be used in complex forest conditions such as the Acadian Region of Maine, New Brunswick (NB), Nova Scotia (NS), and Prince Edward Island

77 (PEI). The specific objectives of this paper were to: 1) compare alternative approaches for 
78 quantifying site productivity; 2) evaluate the relationship of the site productivity measure to a

79 suite of factors including climate, bedrock, soils, drainage, and topography; 3) map productivity

80 at high spatial precision (20 m) for forest research, planning, and management purposes; and 4)

81 compare the performance of the developed index to existing site classification systems.

\section{Methods}

\section{Study area}

The Acadian forest region resides in the transition zone between the conifer-dominant

boreal forests to the north and the broadleaf forests to the south. Three Canadian Maritime Provinces (NB, NS, and PEI) are found in the region, along with southern portions of Québec, and much of the US state of Maine. Across the region, climate estimates indicate average annual precipitation is $1,130 \mathrm{~mm}$ with a range of 870 to $1,750 \mathrm{~mm}$, while mean growing degree days (sum of temperature $>5^{\circ} \mathrm{C}$ ) is 1625 with a range of 726 to 2292 days . Glacial till is the principal soil parent material, with soils ranging from well-drained loams and sandy loams on glacial till ridges to somewhat poorly to very poorly drained soils on flat areas between low-profile ridges. The majority of the Acadian forest is dominated by naturally-regenerated, mixed-species stands that display either even- or uneven-aged stand structures, while some portions of NB contain intensively-managed, single-species plantations. Over 60 tree species are present in the region, and common conifer species include balsam fir [Abies balsamea (L.) Mill.], red spruce [Picea rubens (Sarg.)], white spruce [Picea glauca (Moench) Voss.], eastern white pine [Pinus strobus L.], eastern hemlock [Tsuga canadensis (L.) Carr.], black spruce [Picea mariana (Mill.) B.S.P], and northern white-cedar [Thuja occidentalis L.]. Common hardwoods include red maple [Acer rubrum L.], paper birch [Betula papyrifera Marsh.], gray birch [Betula populifolia Marsh.], yellow birch [Betula alleghaniensis Britt.], quaking aspen [Populus tremuloides Michx.], bigtooth aspen [Populus grandidentata Michx], American beech [Fagus grandifolia 
102 Ehrh.], northern red oak [Quercus rubra L.], and sugar maple (Acer saccharum Marsh.).

\section{Tree Data}

104 Data were compiled from existing forest inventory plots where individual tree growth

105 over time and/or site trees (with co-dominant and dominant tree height vs. age data) had been

106 measured by government and industrial forestry organizations across Maine, NB, NS, and PEI

107 (Table 1). While not considered part of the Acadian forest, southern Maine plots were included

108 to provide wider climatic calibration and possibly more robust productivity estimates.

109 Pre-commercially thinned and planted stands were omitted. Site trees were limited to

110 ages 20 to 100 years old. Plot measurements prior to 1990 were omitted to avoid, as much as

111 possible, effects of the 1970-1980s spruce budworm (Choristoneura fumiferana Clem.) outbreak

112 on growth estimates. Plots with basal area $>75 \mathrm{~m}^{2} \mathrm{ha}^{-1}$ as well as site trees yielding an estimated

113 index height outside the range of 2 to $35 \mathrm{~m}$ (at breast-height age 50) were omitted because these

114 observations are highly unlikely in the Acadian forest and probably result from data entry errors.

115 In total, 8,460 plot locations had at least one balsam fir or spruce site tree, and 6,804 locations

116 had at least one 3-10 year plot growth measurement period (Table 1).

117 Tree above-ground dry biomass was calculated for trees $\geq 9 \mathrm{~cm} \mathrm{DBH}$ using Lambert et al.

118 (2005) tree biomass equations. Plot biomass growth of surviving trees (BG; $\left.\mathrm{kg} \mathrm{ha}^{-1} \mathrm{yr}^{-1}\right)$ from

119 one measurement period to the next was calculated using:

$$
B G_{p m}=\frac{\left(B M_{p m+1}-B M_{p m}\right)}{G S}
$$

121 where $B M$ is above-ground dry biomass of all trees in a plot $p$ that are alive at the start of a plot

122 measurement period $(m)$ that remained alive at the next $(m+1)$ measurement period, and $G S$ is

123 the number of growing seasons between $m$ and $m+1$.

124 Spruce or fir site index (height at breast-height age 50) for each plot was based on the

125 average spruce or fir index calculated for each site tree as a function of breast-height age and 
126 total tree height (Ker and Bowling 1991). Calculated site index was strongly correlated with age

127 and was consistently over-predicted when age was $<50$ and under-predicted when age was $>50$

128 years, based on comparisons with site tree index for different aged trees of the same species in

129 the same plot. This bias was corrected with simple linear regression models of site index over

130 age for each fir and spruce species using plots with multiple site trees.

\section{Site Factors}

132 Various site factors were compiled and derived including those representing climate,

133 lithology, soils, and topography (Table 2). Monthly climate normals data (1971-2000) at $800 \mathrm{~m}$

134 resolution were obtained from McKenney et al. (2006). Lithology and soils data were obtained

135 from various sources. Rock type classification was limited to eight broad groups (Table 3), partly

136 due to difficulty in interpreting lithological descriptions in each jurisdiction, and also to avoid

137 cases where the rock type was restricted to a limited range of climatic or geographic zones.

138 Since lithology is generally correlated to soil fertility and other site factors, a bedrock

139 productivity index (BRI) value between 0 (worst) and 1 (best) using a combination of expert

140 opinion (Colpitts et al. 1995) and partial dependence responses observed during preliminary

141 analysis. The granite type (e.g., quartz, rhyolite, granite) was consistently observed, on average,

142 to result in the worst site productivity of all rock types. Non-calcareous fine sedimentary (e.g.,

143 siltstone and mudstones) bedrock performed as well as weakly calcareous sedimentary and only

144 slightly worse than strongly calcareous (e.g., limestone) bedrock. Low growth difference

145 observed between non-calcareous and calcareous variants of the fine sedimentary rock type was

146 unexpected, but may have occurred because these rock types were often spatially aggregated,

147 and as a result of repeated glaciation, these rock types are likely to be mixed together in soil

148 parent material. Logically, calcareous origins should lead to the highest bedrock productivity

149 score and it was therefore set to one. Mafic (basalt, gabbro) performed slightly better than coarse 
150 sedimentary (e.g., conglomerate, sandstone), but overall, was less than fine sedimentary bedrock.

151 Exact bedrock class index value and rank assigned (Table 3) were somewhat subjective;

152 however, these rankings generally resulted in improved site response trends across jurisdictions

153 based on preliminary analysis. For PEI, a digital bedrock layer was not available. PEI has similar

154 geological origins as eastern NB (sandstone); however, presence of siltstone overlying sandstone

155 in PEI is more common (MacDougall et al. 1988), as is deep soils with few coarse fragments,

156 which suggest the parent material of PEI may be of higher quality for tree growth than in eastern

157 NB. Therefore, PEI was assumed to more closely resemble that of fine sedimentary during

158 regional site modeling. Finally, importance of BRI in the site model during preliminary analysis

159 slightly increased if the BRI value was spatially 'blurred' by calculating an average weighted

160 BRI value using the proportion of area of each rock type within a $10 \mathrm{~km}$ radius of each plot

161 location. One, 5, and $10 \mathrm{~km}$ radii were also explored, but the $10 \mathrm{~km}$ radius performed best.

162 Various soil attributes were also examined ( $\mathrm{pH}$, various horizon depth summaries, \%

163 coarse fragments, texture, soil water holding capacity, mode of deposition), but preliminary

164 analysis indicated that only mineral soil root restriction depth (RRD; e.g., depth to hardpan or

165 bedrock, up to $100 \mathrm{~cm})$ and to a lesser extent \% coarse fragments $(\mathrm{CF})$ showed consistent

166 moderate to weak correlation with site productivity measures, overall and within each

167 jurisdiction. As these two soil attributes were highly correlated and both act to limit soil rooting

168 volume (water, nutrients), a unified index of root growing space (RGS) was calculated as:

$169 \quad R G S=R R D *\left(1-\left(C F_{\text {top } 30}+C F_{m}\right) / 200\right)$

170 where $C F_{\text {top } 30}$ is $C F$ measured in the top $30 \mathrm{~cm}$ of mineral soil, and $C F_{m}$ is $C F$ measured from the

171 top of mineral soil to the lesser of root restriction depth or $100 \mathrm{~cm}$. When CF was available for

172 each mineral soil horizon (all regions except NB), mean CF was weighted by the proportional

173 depth of each horizon in $C F_{\text {top } 30}$ and $C F_{m}$. Only categorical classes of CF were available for NB, 
174 which were translated into numeric proportions based on class mid-point values.

175 RGS explained roughly the same degree of site variability compared to using RRD and

$176 \mathrm{CF}$; however, differences observed near jurisdiction borders were visually reduced compared to

177 RRD and CF alone. RGS was mapped at 50m resolution and set to zero for areas with extensive

178 rock outcrops or barren land and to -1 for wetlands, bogs, and other very poorly drained areas

179 identified in available forest photo-interpreted shapefiles (1:12,500 scale) in NB, NS, and PEI. In

180 Maine, the US National Wetland Inventory from the US Fish and Wildlife Service was used to

181 improve resolution of wetlands and bogs in the RGS layer.

182 A variety a topographic variables were derived based on existing digital elevation models

183 (DEMs) for each jurisdiction; resolution ranged from 6-90 m. Topographical variables included

184 elevation, depth to water (DTW; Murphy et al. 2009), slope $\left(^{\circ}\right)$, solar radiation (Fu and Rich

185 2002), and System for Automated Geoscientific Analyses (SAGA) terrain indices (Böhner et al.

186 2006) such as topographic wetness, roughness, positive openness, and slope position class.

\section{Data Analysis}

$\mathrm{BG}$ and site index response to site factors were explored using the nonparametric ensemble regression tree algorithm, Random Forests (Breiman 2001). Site factors that showed relatively consistent effects on site in each jurisdiction were selected and refined for use in the

191 final site model. In addition, stand structural measures (biomass, basal area, density, quadratic 192 mean diameter) and species basal area proportions were examined as background effects likely 193 to influence observed growth.

194 BG was favored over site index as a measure of site productivity because preliminary analysis indicated that: 1) tree site index was not correlated to any site factors tested in Maine, 2)

196 BG could be estimated for a larger set of sample locations and with more trees contributing to 197 the growth signal at each location for most jurisdictions (Table 1), and 3) stand metrics like BG 
198 are more robust measures of site productivity than tree-based ones like site index. In addition,

199 due to the inability of Random Forests to 1) extrapolate beyond the underlying data and 2) factor

200 out effects of stand species structure, the final BG model was fit using generalized non-linear

201 least squares with R package nlme (Pinheiro and Bates 2015). Influential predictors identified

202 using Random Forests were carried forward into development of this equation to predict BG as a

203 combination of site and stand structural and compositional metrics. Final BG model form and

204 predictors selected were based on predictor significance and minimizing model Akaike

205 information criterion score. Preliminary analysis indicated the best model form was a Chapman-

206 Richards equation and 15,622 plot growth measurements were used to simultaneously fit the

207 final model (eq. 3-7):

$208 B G_{p m}=$

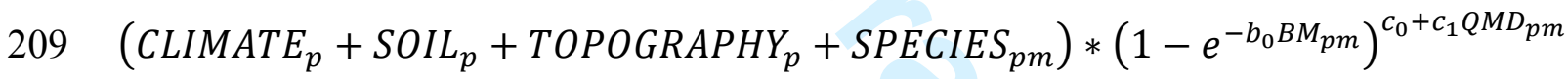

211 CLIMATE $_{p}=a_{0}+a_{1}$ FrostFreeDays $_{p}+a_{2}$ AvgGrowingTemperature $_{p}$

$212 \operatorname{SOIL}_{p}=a_{3} \ln \left(R G S_{p}+10\right)+a_{4} B R I_{p}$

213 TOPOGRAPHY $=a_{5} \ln \left(D_{T} W_{p}+0.0001\right)+a_{6}\left(S L O P E_{p}^{S_{0}} * e^{-s_{1} S L O P E_{p}}\right)$

$214 \quad$ SPECIES $_{p m}=a_{7} P O P L A R_{p m}+a_{8} P I N E_{p m}$

215 where the asymptote of maximum biomass productivity was defined by a combination of site

216 factors (CLIMATE, SOIL, TOPOGRAPHY; see Table 3 for variable descriptions) and SPECIES

217 factors (\% basal area of POPLAR and PINE) with parameters $a_{0} . . a_{8}, s_{0}$, and $s_{1}$; the growth rate

218 parameter $b_{0}$ was influenced by plot above-ground dry-biomass $(\mathrm{BM})$ at time 0 surviving to time

219 1; and the shape parameters $c_{0}$ and $c_{1}$ were influenced by the quadratic mean diameter (QMD) at

220 time 0 . All site variable values were bilinear-interpolated for each plot location $(p)$, while stand 
221 variables, including BG, were calculated for each plot measurement period $(m)$. To address

222 heteroscedacity, a variance power function was included in the final model.

223 While holding species covariates at zero, the asymptote of the BG model was calculated

224 for all plots and also mapped across the region on a $20 \mathrm{~m}$ grid by bilinear interpolating site

225 variables for each $x, y$ coordinate and termed the biomass growth index (BGI; maximum $\mathrm{kg} \mathrm{ha}^{-1}$ $\left.226 \mathrm{yr}^{-1}\right)$ as:

227

$$
B G I_{x y}=C L I M A T E_{x y}+S O I L_{x y}+T O P O G R A P H Y_{x y}
$$

Ability of the BGI model to explain variation in average spruce and fir site index observed across all plot locations was evaluated using Random Forests. The same was done for comparison purposes using current classifications of site productivity in NB (ecological land class; Zelazny et al., 2007), NS (forest photo-interpreted land capability class; NSDNR, 2015), and PEI (soils-based forestland capability class; MacDougall et al., 1988). Finally, incremental improvement of using both BGI and land classification together to explain variation in site index was also examined.

\section{Results}

\section{Effects of climate}

Most climate variables (Table 2) were moderately to weakly correlated with observed

BG, but as expected, were also strongly correlated to one another (e.g., maximum vs. mean temperature). Some climate variables (e.g., summer precipitation) were strongly correlated with BG, but also with other site factors (e.g., elevation, bedrock). Variables were dropped if little or no model error reduction occurred when they were removed, or if the relationship of the variable to $\mathrm{BG}$ varied from negative to positive or from strong to weak when examining relationships

244 across each jurisdiction. The only climate variables retained in the final model were average 
245 growing season temperature and frost free days; however, May-September average temperature 246 was a close alternative and performed nearly as well on its own. Temperature was consistently

247 important regardless of jurisdiction and contributed significantly to the final model.

\section{Effects of lithology and soils}

Second only to temperature (mean growing season temperature + frost free days) in

250

251

252

253

254

255

256

257

258

259

260

261

262

263

264

265

266

267

268

contribution to model error reduction was underlying lithology (rock type). Rock type was important in all jurisdictions, excluding PEI, which was assumed to have a similar rock type throughout. The continuous measure of BRI always outperformed the categorical representation of rock type in the model. Soil influence on BG was moderate-weak in NS and PEI, and weakpoor in Maine and NB. BG log-linearly declined with RGS overall and within each jurisdiction; however, RGS was not a strong relative predictor in the final model because of issues with consistent and reliable soil mapping previously discussed.

\section{Effects of topography and drainage}

BG was negatively correlated with elevation, but elevation was highly correlated with temperature. Elevation resulted in almost no model improvement when temperature was included, and therefore was dropped from the final model. Slope was the strongest and most consistent topographical site predictor across all jurisdictions and BG generally increased logarithmically with it, peaked at $5-10^{\circ}$, and then declined linearly thereafter. As with slope, BG also logarithmically increased with DTW, especially between 0 and $10 \mathrm{~cm}$. DTW generally outperformed topographic wetness index, but only slightly, and both drainage measures only weakly improved overall BG variance explained. DTW, while important, was the least significant variable retained in the final model.

\section{Effects of stand species and structure}

$\mathrm{BM}$ and $\mathrm{QMD} \geq 9 \mathrm{~cm} \mathrm{DBH}$ explained more variability in $\mathrm{BG}$ than all other site factors 
269

270

271

272

273

274

275

276

277

278

279

280

combined. Using BM and QMD alone removed most residual model bias when plotted against other stand structural metrics (basal area, density, and height) and also for most species

proportions in the plot. BG was increasingly under predicted as proportions of poplar or pine increased, so these species were incorporated into the final site model.

\section{Biomass growth model}

All BG parameters were highly significant $(P<0.0001$; Table 4$)$ and together explained $65.2 \%$ of total BG variation across the region: $41 \%$ in Maine $(n=4,225), 35 \%$ in NB $(n=$ 4,201), $51 \%$ in NS $(n=7,063)$, and $13 \%$ in PEI $(n=161)$. Approximately $50 \%$ of the total variance explained was attributable to site factors based on Random Forests analysis. The model under predicted biomass growth in Maine by $7.2 \%$ and over predicted growth in NS by $1.6 \%$, in NB by $5.5 \%$, and in PEI by $1.8 \%$. Forty-eight percent of plots had mean residual error $<500 \mathrm{~kg}$ $\mathrm{ha}^{-1} \mathrm{yr}^{-1}$. Influence of site and structural variables on BG is presented in Fig. 1.

Plot mean BG residual error (observed - predicted) was spatially interpolated across the region using ordinary kriging in ESRI ArcGIS version 10.1 with a minimum of 20 plot neighbour samples and $5 \mathrm{~km}$ raster cell size (Fig. 2). In many cases, spatial distribution of errors suggested that areas with concentrated low productivity sites (e.g., NB lowlands/highlands, NS southeast shore) are less productive than predicted, and areas of concentrated high productivity sites (e.g., northwestern NB; southwest ME) are more productive than predicted; however, in many other cases, pockets of spatial bias are not readily explainable. Indication of diluted BG predictions at site extremes may have resulted from noisy plot data and spatial inaccuracies in site predictors. Approximately $50 \%$ of the total variance explained was attributable to site factors based on Random Forests analysis.

\section{Biomass growth index}

The asymptote of the BG model with species held constant at zero (BGI) was mapped at 
$29320 \mathrm{~m}$ resolution for each jurisdiction (Fig. 3). Highest rates of BGI were predicted in parts of

294 southern and central Maine as a function of warmer growing conditions, deep soils, and fine

295 sedimentary bedrock origins. Reduced productivity visually corresponded with one or more of

296 the following conditions: highlands and cool coastal areas, poorly drained local topography, or

297 areas with poor soils and/or bedrock.

298 Observed range of BG measured across the region was between 0 and 15,380 $\mathrm{kg} \mathrm{ha}^{-1} \mathrm{yr}^{-1}$ 299 and averaged 2,541 $\pm 1,299 \mathrm{SD} \mathrm{kg} \mathrm{ha}^{-1} \mathrm{yr}^{-1}$; however, samples were not equally distributed across

300 the region. BGI predictions $\left(\mathrm{kg} \mathrm{ha}^{-1} \mathrm{yr}^{-1}\right)$ in each jurisdiction ranged from: 0-5,872 (mean

301 3,975 \pm 688 SD) in Maine; 797-5,320 (mean 3,498 \pm 524 SD) in NB; 2,086-4,841 (mean

$3024,111 \pm 429$ SD) in PEI; and 328-4,908 (mean 3,239 \pm 626 SD) in NS.

303 Comparison to spruce and balsam fir site trees

304 For Maine plots, there was no correlation between predicted BGI and plot spruce or fir

305 site index, though spruce or fir site index in Maine was not correlated to any site predictors tested

306 either. In Maine plots, only a single site tree is collected in a clustered plot design, this tree is

307 sometimes outside of the plot, and age is often determined in the field, which can be problematic

308 for species with slow growth, periods of suppression, or difficult to discern tree rings. These

309 factors combined likely contribute to substantial noise in the Maine site tree data used.

310 For Maritime Canada, BGI explained low amounts of variation $(<35 \%$; Fig. 4) in spruce

311 or fir site index depending on region and dataset, but was generally comparable to the level of

312 site index explained by existing provincial site productivity classifications (Table 5). Our results

313 for spruce site index slightly outperformed the NB ecological land classification, and slightly to

314 moderately underperformed the NS and PEI land capability classification. Interestingly, for NS

315 and PEI, 1-10\% more absolute site index variation was explained when both the BGI and

316 provincial site productivity layers were used together to predict site index (Table 5). For NB, 
317 there seemed to be little value in using the mapped ecological land classification, alone or in

318 combination with BGI, to predict site index.

320

\section{Discussion}

An ideal measure of site productivity should be integrative, independent of species, easy

322 to measure or assess, and robust to various factors like changes in stand age. Site index meets

323 many of these metrics, but has important limitations and can be difficult to apply in mixed-

324 species and multi-cohort stands. Consequently, this analysis sought to develop a new biomass

325 increment-based index of productivity, compare it to existing measures of site productivity, and

326 map it across the entire region at a high spatial resolution.

327 Overall, BGI relationship to various site factors like climate, soils, and topography was

328 logical, consistent when examined independently in each region, and the measure generally

329 outperformed existing approaches to site productivity in the region. BGI performed well as the

330 effects of species composition and stand structure were effectively removed, a relatively strong

331 relationship between various site factors like climate, soils, and topography was observed, and

332 the measure generally outperformed existing approaches to site productivity in the region. By

333 incorporating background stand structure and species factors explicitly in the BG equation, and

334 then holding those variables constant while predicting BGI, we removed, as much as possible,

335 those background effects. However, because we do not possess data covering all combinations of

336 site and stand conditions, and because stocking is often positively correlated with site quality

337 (e.g., tree bogs and rock outcrops have non-stockable area), we wanted to be sure that BGI was

338 not somehow confounded by this unbalanced dataset. When site variables used in the BGI model

339 were used to predict spruce site index with Random Forests, little additional site index variability

$340(<1 \%)$ was explained compared to using only BGI. This result suggests that BGI, despite 
341 somewhat confounding modelling issues of stand structure and species, is capturing important

342 aspects of soils, landform, bedrock, and climate with respect to forest productivity.

343 Consequently, BGI should prove useful for future research and forest planning and management

344 efforts.

345 Stand-level, increment-based approaches such as the one used in this analysis are likely

346 an improvement to tree-level ones since finding undamaged, free to grow trees can be difficult

347 (e.g., Nigh and Love 1999) and tree dominance can vary through stand development (e.g.,

348 Raulier et al. 2003). Plus, individual tree diameter and height increments are influenced by a

349 broader range of factors when compared to stand-level increments (Weiskittel et al. 2011b),

350 which could make determining the most influential site factors more difficult. A similar issue

351 may also be present at the stand-level as Berrill and O'Hara (2016) recently found that stand

352 dominant height and basal area were responsive to different site factors in mixed conifer forests

353 in California, USA. In this analysis, stand-level biomass increment was used as it was believed to

354 better measure of site productivity for mixed species stands because it considered differences in

355 species wood density, compared to previous stand-level increment-based productivity indices

356 that have used either basal area (Berrill and O'Hara 2014) or volume increment (Schmoldt et al.

357 1985). However, these analyses had fewer species present when compared to the current analysis

358 so the correlation between basal area, volume, and biomass was likely stronger. Importantly, the

359 species-specific biomass equations used in this analysis were a function of both DBH and height

360 unlike most DBH-only biomass equations.

361 Like Jiang et al. (2015), climate was found to be a much better predictor of site

362 productivity when compared to soils variables after accounting for differences in stand

363 composition and structure. Unlike Jiang et al. (2015), temperature variables like frost free days

364 and growing season temperature were most influential in our analysis, whereas precipitation and 
365 its interaction with temperature were much more important in the other analysis. This is likely 366 related to the spatial scale of the assessment as Jiang et al. (2015) were assessing at a much

367 broader scale by focusing on the eastern US and consequently, precipitation would likely vary 368 more dramatically than it does within a single region. Regardless, there is a large range of 369 climate conditions in the Acadian Region due to the mixture of coastal and mountainous areas, 370 so it is logical to expect climate to be a primary predictor of productivity. In fact, seven 371 climatically distinct regions exist just in Maine (Briggs and Lemin 1992) and the range of 372 variation observed is equivalent to the variation observed across $20^{\circ}$ of latitude in Europe 373 (Jacobson et al. 2009).

374 Climate, lithology, and soils vary considerably in the Acadian Region when compared to 375 other regions. Consequently, their importance was expected to be greater than what was 376 observed in Jiang et al. (2015). Although this was generally the case in this analysis, the degree 377 of improvement was relatively marginal. For example, soil influences were moderate to weak in 378 NS and PEI, and weak to poor in Maine and NB, which suggests that more effort is needed to 379 accurately and more precisely map soil attributes that drive productivity in the Acadian forest 380 region. In NB, soil types are assigned to broad polygons throughout the province and only 381 qualitative descriptions of attributes by soil type, regardless of polygon location, are available 382 (Colpitts et al. 1995). In Maine, soil polygon profiles sometimes vary more across township 383 borders than within townships. For all jurisdictions, adjacent polygon differences in soil depth 384 and other attributes are often extreme, suggesting considerable mapping error. These soil 385 polygons often include more than one soil type with proportions stated, but not mapped. A shift 386 toward mapping gradations in rooting depth, $\%$ coarse fragments, $\%$ sand, etc. at high resolution $387(20 \mathrm{~m})$ as a function of topographic metrics, rather than the current approach of broadly mapping 388 collections of associated soil types in polygons tied to hard breaks in drainage, landform, and 
389 slope class, would probably help to improve soil predictions at fine scales.

390 Despite these findings, both BRI and RGS proved to be significant predictors and can

391 likely be improved upon. Although BRI was a subjective measure developed in this analysis, it

392 was more effective than using lithology as a categorical variable and provides a logical link to

393 soil fertility (e.g., Colpitts et al. 1995). For example, siltstone is not necessarily considered

394 nutrient rich, but it weathers relatively quickly and often results in deep silty loams. In contrast,

395 basalt, which contains higher concentrations of calcium and magnesium, weathers more slowly

396 and often results in shallower soils with moderate to high percentages of coarse fragments. In

397 contrast, granite is often associated with low productivity because it 1) weathers slowly, 2) has

398 low concentrations of calcium and magnesium, 3) occurs frequently in high-elevation

399 environments (cold) in the Acadian forest region, and 4) because soils derived from granite tend

400 to be sandy and rocky. These correlations and interactions make it challenging to capture the true

401 relationship between rock type and productivity, as illustrated in this analysis. Briggs (1994)

402 found that soil root depth was an important variable in his analysis of site factors in Maine,

403 which is consistent with the use of RGS in this analysis. In contrast, Steinman (1992) found that

404 chemical soil variables were generally better predictors than physical soil variables in predicting

405 both spruce-fir site index and mean annual increment in Maine. Interestingly, RGS slightly

406 outperformed derived soil water holding capacity, which would capture differences in soil

407 texture. Both RGS and BRI are interesting variables and should be further explored in future

408 analyses in this region.

409 Topographic indices have performed well in previous site productivity analyses (McNab

410 2010; Stage and Salas 2007) and were expected to be important in this region given the range of

411 topographic complexity present. In this analysis, slope and DTW were the most effective

412 predictors among the numerous topographic indices tested. The importance of slope has been 
413 reported in previous studies (e.g., Grant 2004; Weiskittel et al. 2007), but generally it is in 414 conjunction with aspect as it influences the amount and type of incoming radiation (e.g., Stage 415 and Salas 2007). In the Acadian Region, slope is often related to soil drainage given a high 416 proportion of low-lying flat areas whose wetness can negatively impact tree growth. DTW often 417 approaches zero in very poorly drained flat black spruce bogs, but can also approach zero near a 418 gently sloping stream bank or near a productive alluvial terrace. Interestingly, large topographic419 related declines in site productivity were only observed to occur when both slope and DTW 420 declined to zero.

421 To a certain extent, slope and DWT interacted, and helped to differentiate between low 422 DTW on sloping terrain (good productivity) and flat terrain (poorly drained), although direct 423 variable interactions were not significant in the final model. Underlying errors and the large 424 range in spatial resolutions used in this analysis are speculated to have reduced the true value of 425 topographic variables since a minor rise of only $25 \mathrm{~cm}$ elevation can drastically improve site 426 productivity on otherwise flat terrain where drainage is a limiting factor. Future DEM 427 improvements via LiDAR (light ranging and detection), and perhaps through new algorithms that 428 can measure the stagnancy of the water table, are likely to improve the prediction importance of 429 topographic measures explored here.

Site index remains the primary means of estimating and evaluating site productivity, but 431 its application in mixed-species and multi-cohort stands is problematic. Our biomass increment432 based index of site productivity offers several advantages over both site index and ecological 433 land classification systems. In particular, BGI provides higher spatial resolution of site 434 productivity, is a continuous measure, and can therefore be readily used in tree and stand growth 435 and yield modeling. Often, productivity differences within an ecological land classification class 436 are higher than between classes (e.g. Fig. 3.3 in Weiskittel et al. 2011b) and some classes may 
437 lack sufficient plot data to parameterize growth models for each class. Site index can be highly

438 variable based on stand age (as observed in this study), generally requires multiple measurements

439 per stand, and depends on having a robust, well-constructed site index equation. The lack of

440 strong relationship between site factors and observed site index in Maine is likely related to only

441 one site tree being measured at each plot location, the age determined in the field, and the

442 selected tree not always being located on the plot. In contrast, biomass increment-based indices

443 of site productivity, particularly stand-level ones, will be less variable, show a stronger link to

444 site factors, and be more integrative of the site conditions, but require the effects of stand

445 composition and structure be removed as highlighted in this analysis. In addition, the approach

446 outlined in this analysis needs only one plot growth measurement rather than multiple repeated

447 measurements needed to estimate a plot-level asymptote in yield (e.g., Schmoldt et al. 1985).

448

449 Conclusions

450

451

combination of climate, lithology, soils, and topography was found to be influential on biomass

452

growth rate; with temperature, soil depth and fertility, and slope being the most important. The

453

model explained $65.2 \%$ of the original variation in BG, suggesting potential for additional

454

improvement. Mapping predicted BGI (defined as the maximum BG) across the region produced

455 logical trends that were generally consistent with existing site productivity estimates. BGI

456 predictions for each region (Fig. 3) can be downloaded at www.forusresearch.com $\backslash$ bgi.php.

457 Continued measurement of permanent plots as well as improvements in the estimation of the

458 underlying variables, particularly with respect to advancements in digital elevation and soil

459 attribute mapping with LiDAR and other satellite remote sensing information, should provide

460 additional opportunities to improve this index. 
Overall, BGI predictions should prove useful for future research and forest planning and

462

463

464

465

466

467

468

469

470

471

472

473

474

475

476

477

478

479

480

481

482

483

484

\section{9}

\section{Acknowledgements}

Funding was supported by the University of Maine Cooperative Forest Research Unit, Maine Agricultural and Forest Experiment Station, NB Department of Natural Resources (NBDNR), and PEI Department of Forestry, Fish and Wildlife (PEIFFW). Special thanks to:

Sean Lamb and Evan Dracup (University of New Brunswick) for data compilation and management; Paul Arp (University of New Brunswick), Mark Colpitts (NBDNR), and Kevin Keys (NS Department of Natural Resources; NSDNR) for helpful discussions. Individuals assisting with substantial information sharing and interpretation: Adam Dick and Dale Wilson (NBDNR); Mike Montigny (PEIFFW); Chris Bailey, James Bruce, Peter Neily, and Kevin Keys (NSDNR); Jody Jenkins (Acadian Timber Inc.); Shona Millican, David Young, and Greg Adams (J.D. Irving, Limited); Dan McKenney and Pia Papadopol (Natural Resources Canada); and Shane Furze and Mark Castonguay (Forest Watershed Research Centre, University of New Brunswick). Reviewers provided valuable comments that improved the paper.

\section{References}

Berrill, J.-P and O'Hara, K.L. 2014. Estimating site productivity in irregular stand structures by indexing the basal area or volume increment of the dominant species. Can. J. For. Res. 44(1): 92-100. doi: 10.1139/cjfr-2013-0230.

Berrill, J.-P. and O’Hara, K.L. 2016. How do biophysical factors contribute to height and basal 
area development in a mixed multiaged coast redwood stand? Forestry 89: 170-181. doi:10.1093/forestry/cpv049

487

Böhner, J., McCloy, K.R., and Strobl, J. [Eds.]. 2006. SAGA - Analysis and Modelling Applications. Göttinger Geographische Abhandlungen, Vol. 115, 130p.

Breiman, L. 2001. Random Forests. Machine Learning: 45(1): 5-32.

$$
\text { doi:10.1023/A:1010933404324. }
$$

Briggs, R.D. 1994. Site classification field guide. Cooperative Forest Research Unit, University of Maine, Orono, Maine. Tech. Rep. 6.

Briggs, R.D. and Lemin Jr, R.C. 1992. Delineation of climatic regions in Maine. Can. J. For. Res. 22(6): 801-811. doi:10.1139/x92-109

AAFC. 1998. Canada Land Inventory, National Soil DataBase, Agriculture and Agri-Food Canada. Available from http://sis.agr.gc.ca/cansis/nsdb/cli/index.html [accessed 20 April 2016].

CANSIS. 2014. Detailed soil survey compilations of Nova Scotia and Prince Edward Island. Scale 1:75,000, Version 3. Canadian Soil Information Service (CANSIS), Agriculture and Agri-Food Canada. Available from http://sis.agr.gc.ca/cansis/nsdb/dss/v3/index.html [accessed 20 April 2016].

Carmean, W.H. 1975. Forest site quality evaluation in the United States. Adv. Agron. 27: 209269. doi:10.1016/S0065-2113(08)70011-7

Carmean, W.H. 1979. A comparison of site index curves for northern hardwood species. USDA Forest Service, North Central Forest Experiment Station; Res. Pap. NC-167. 12 p. Colpitts, M.C., Fahmy, S.H., MacDougall, J.E., Ng, T.T.M., McInnis, B.G., and Zelazny, V.F. 1995. Forest soils of New Brunswick. Agriculture and Agri-Food Canada Res. Br., Nat. Res. Canada. Centre for Land and Biological Resource Research Contribution No. 95-38. 
$52 \mathrm{p}$.

510 Coops, N.C., Gaulton, R., and Waring, R.H. 2011. Mapping site indices for five Pacific

$511 \quad$ Northwest conifers using a physiologically based model. Appl. Veg. Sci. 14: 268-276. doi:10.1111/j.1654-109X.2010.01109.x

513 Curtis, R. and Post, B.W. 1964. Basal area, volume, and diameter related to site index and age in unmanaged even-aged northern hardwoods in the Green Mountains. For. Sci. 62: 864-

515 870.

516 Fu, P. and Rich, P.M. 2002. A geometric solar radiation model with applications in agriculture 517 and forestry. Comp. Elec. Agr. 37(1): 25-35. doi:10.1016/S0168-1699(02)00115-1

Goelz, J.C.G. and Burk, T.E. 1992. Development of a well-behaved site index equation: jack pine in north central Ontario. Can. J. For. Res. 22(6): 776-784. doi:10.1139/x92-106

Grant, R.F. 2004. Modeling topographic effects on net ecosystem productivity of boreal black

Griffin, R.H. and Johnson, J.E. 1980. Polymorphic site index curves for spruce and balsam fir growing in even-aged stands in northern Maine. University of Maine, Orono, Maine. Agricultural Experiment Station. Bulletin 765. 22p.

Hamel, B., Bélanger, N., and Paré, D. 2004. Productivity of black spruce and Jack pine stands in Quebec as related to climate, site biological features and soil properties. For. Ecol. Manage. 191: 239-251. doi:10.1016/j.foreco.2003.12.004 Maine's climate yesterday, today, and tomorrow. In: Jacobson, G.L., Fernandez, I.J., Mayewski, P.A. and Schmitt, C.V. (Eds.). Maine's climate future: An initial assessment. University of Maine, Orono, ME. p. 9-13. Available from http://www.climatechange.umaine.edu/mainesclimatefuture/ [accessed 20 April 2016]. 
533 Jiang, H., Radtke, P.J., Weiskittel, A.R., Coulston, J.W., and Guertin, P.J. 2015. Climate- and

534

535

536

537

538

539

540

541

542

543

544

545

546

547

548

549

550

551

552

553

554

555

556 soil-based models of site productivity in eastern US tree species. Can. J. For. Res. 45(3): 325-342. doi:10.1139/cjfr-2014-0054.

Keppie, J.D. 2000. Digital version of map ME 2000-1, Geological Map of the Province of Nova Scotia, Scale 1:500 000. Fisher, B.E. and Poole, J.C. 2006 [digital eds.]. DP ME 43, Version 2. Mineral Resources Branch, Nova Scotia Dept. of Nat. Res., Halifax, Nova Scotia. Available from http://novascotia.ca/natr/meb/download/gis-data-maps.asp [accessed 20 April 2016].

Ker, M.F. and Bowling, C. 1991. Polymorphic site index equations for four New Brunswick softwood species. Can. J. For. Res. 21(5): 728-732. doi:10.1139/x91-103.

Keys, K., Neily, P., Quigley, E., and Stewart, B. 2010. Forest Ecosystem Classification for Nova Scotia. Nova Scotia Dept. Nat. Res., Renewable Res. Br., Report FOR 2011-2. 92p. Available from http://novascotia.ca/natr/library/forestry/reports/Ecosites.pdf [accessed 20 April 2016]

Lambert, M.C., Ung, C.H., and Raulier, F. 2005. Canadian national tree aboveground biomass equations. Can. J. For. Res. 35(8): 1996-2018. doi:10.1139/x05-112.

MacDougall, J.I., Veer, C., and Wilson, F. 1988. Soils of Prince Edward Island. Research Branch, Agriculture Canada, Charlottetown, P.E.I. Land Resource Research Centre, Contribution No. 83-54. 210p. Available from http://www.gov.pe.ca/gis/index.php3?number=77555\&lang=E [accessed 20 April 2016].

Maine. 2015. Digital bedrock geologic map of Maine. Original authors: Osberg, Hussey, and Boone, 1985. Maine geological survey, Dept. Conserv., State of Maine. Available from http://www.maine.gov/megis/catalog/ [accessed 20 April 2016].

McKenney, D.W., Pedlar, J.H., Papadopol, P., and Hutchinson, M.F. 2006. The development of 
1901-2000 historical monthly climate models for Canada and the United Stated. Agri. For. Met. 138(1-4): 69-81. doi:10.1016/j.agrformet.2006.03.012.

McNab, W.H. 2010. Effects of landform on site index for two mesophytic tree species in the Appalachian Mountains of North Carolina, USA. Inter. J. For. Res. 2010: 298674.

561 doi:10.1155/2010/298674

\section{2} 563

Monserud, R.A. 1984. Height growth and site index curves for inland Douglas-fir based on stem analysis data and forest habitat type. For. Sci. 30(4): 943-965.

564 Murphy, P.N.C., Ogilvie, J., and Arp, P.A. 2009. Topographic modelling of soil moisture 565 conditions: a comparison and verification of two models. Europ. J. Soil Sci. 60(1): 94109. doi: 10.1111/j.1365-2389.2008.01094.x.

NBDNR. 2008. Bedrock geology of New Brunswick. Minerals, Policy and Planning Division, 568 New Brunswick Dep. Natural Resources, Fredericton, NB. Map NR-1. Scale 1:500 000 (revised December 2008). Available from http://www2.gnb.ca/content/dam/gnb/Departments/en/pdf/MineralsMinerales/Bedrock_Geology_MapNR1-e.pdf [accessed 20 April 2016].

NBDNR. 2015. Photo-interpreted forest inventory, captured 2003-2012. Digital shapefile. New Brunswick Dep. Natural Resources, Fredericton, NB [assessed 25 Sept 2015]. conversion equations for species in mixed stands. For. Sci. 41(1): 84-98.

Nigh, G.D. and Love, B.A. 1999. How well can we select undamaged site trees for estimating site index? Can. J. For. Res. 29(12): 1989-1992. doi:10.1139/x99-163. Resources, Truro, NS. Available from www.novascotia.ca/natr/forestry/maps-and-forestinfo.asp [accessed 20 April 2016]. 
581 Pinheiro, J. and Bates, D. 2015. Linear and nonlinear mixed effects models. R package: nlme

582

583

584

585

586

587 version 3-1-122. 335p. Available from https://cran.rproject.org/web/packages/nlme/nlme.pdf [accessed 20 April 2016].

PEIFFW 2015. Photo-interpreted forest inventory, updated to 2015. Digital Shapefile. Prince Edward Island Dep. Forests, Fish and Wildlife, Charlottetown, Prince Edward Island. Available from http://www.gov.pe.ca/gis/index.php3?number=77555\&lang=E [accessed 20 April 2016].

Raulier, F., Lambert, M., Pothier, D., and Ung, C. 2003. Impact of dominant tree dynamics on site index curves. For. Ecol. Manage. 184(1-3): 65-78. doi: 10.1016/S0378$1127(03) 00149-X$

Saxton, K.E. and Rawls, W.J. 2006. Soil water characteristic estimates by texture and organic matter for hydrologic solutions. Soil Sci. Soc. Am. J. 70(5): 1569-1578. doi:10.2136/sssaj2005.0117

Schmoldt, D.L., Martin, G.L., and Bockheim, J.G. 1985. Yield-based measures of northern hardwood site quality and their correlation with soil-site factors. For. Sci. 31: 209-219.

Skovsgaard, J.P. and Vanclay, J.K. 2008. Forest site productivity: a review of the evolution of dendrometric concepts for even-aged stands. Forestry 81(1): 13-31. doi: 10.1093/forestry/cpm041.

Skovsgaard, J.P. and Vanclay, J.K. 2013. Forest site productivity: a review of spatial and temporal variability in natural site conditions. Forestry 86(3): 305-315. doi:10.1093/forestry/cpt010.

Solomon, D.S., Herman, D., and Leak, W. 1995. FIBER 3.0: an ecological growth model for northeastern forest types. USDA Forest Service, Northeastern Forest Experiment Station, General Technical Report NE-204. 24p. 
605 Stage, A.R., 1963. A mathematical approach to polymorphic site index curves for grand fir. For. $606 \quad$ Sci. 9: 167-180.

607 Stage, A.R. and Salas, C. 2007. Interactions of elevation, aspect, and slope in models of forest 608 species composition and productivity. For. Sci. 53(4): 486-492.

609 Steinman, J.R. 1992. A comprehensive evaluation of spruce-fir growth and yield in Maine as 610 related to physical and chemical soil properties. PhD dissertation. University of Maine, $611 \quad$ Orono, ME. 124p.

612 Swenson, J.J., Waring, R.H., Fan, W.H., and Coops, N.C. 2005. Predicting site index with a 613 physiologically based growth model across Oregon, USA. Can. J. For. Res. 35: 1697614 1707. doi:10.1039/x05-089

615 USDA. 2015. Soils Shapefile for Maine, Scale 1:12,500. Soil Data Mart, Soil Survey Geographic 616 Database. Nat. Res. Conserv. Serv., US Dep. Agric. Available from 617 http://websoilsurvey.nrcs.usda.gov/app/WebSoilSurvey.aspx [accessed 20 April 2016].

618 Vanclay, J. 1989. Site productivity assessment in rainforests: an objective approach using 619 indicator species. In: Mohd, W.R., Chan, H.T. and Appanah, S. (Eds.). Semin. Growth 620 Yield Trop. Mix. For., Kuala Lumpur, Malaysia. pp. 225-241. Available from http://espace.library.uq.edu.au/wiew/UQ:8396 [accessed 20 April 2016].

622 Vicary, B.P., Brann, T.B., and Griffin, R.H. 1984. Base-age invariant polymorphic site index 623 curves for even-age spruce-fir stands in Maine. University of Maine, Agricultural Experiment Station, Orono, Maine. Bulletin 802. 33p.

625

Wang, G.G. 1998. An ecologically based model for site index conversion among species. Can. J.

626 For. Res. 28(2): 234-238. doi: 10.1139/x97-214.

627 Weiskittel, A.R., Garber, S.M., Johnson, G.P., Maguire, D.A. and Monserud, R.A. 2007. Annualized diameter and height growth equations for Pacific Northwest plantation-grown 
Douglas-fir, western hemlock, and red alder. For. Ecol. Manage. 250(3): 266-278.

630 doi:10.1016/j.foreco.2007.05.026

631 Weiskittel, A.R., Crookston, N.L., and Radtke, P.J. 2011a. Linking climate, gross primary productivity, and site index across forests of the western United States. Can. J. For. Res.

633 41: 1710-1721. doi:10.1139/x11-086

634 Weiskittel, A.R., Hann, D.W., Kershaw, J.A., and Vanclay, J.K. 2011b. Forest Growth and Yield 635 Modeling. Wiley, West Sussex, UK. 415 p. doi:10.1002/9781119998518

Williams, R.A., Hoffman, B.F., and Seymour, R.S. 1991. Comparison of site index and biomass production of spruce-fir stands by soil drainage class in Maine. For. Ecol. Manage. 41(3-

638 4): 279-290. doi:10.1016/0378-1127(91)90109-9.

639

Zelazny, V. [ed.] 2007. Our landscape heritage: the story of ecological land classification in New

640 Brunswick. $2^{\text {nd }}$ Ed. New Brunswick Dept. Nat. Res., Fredericton, New Brunswick. 360p. Available from http://www2.gnb.ca/content/dam/gnb/Departments/nr-

642 $\underline{\mathrm{rn} / \mathrm{pdf} / \mathrm{en} / \text { ForestsCrownLands/ProtectedNaturalAreas/OurLandscapeHeritage/ForewordIn }}$

643 troduction-e.pdf [accessed 20 April 2016]. 
644 Table 1. Acadian forest inventory data used for model development and evaluation.

\section{Number of Spruce and Fir Site Index}

Trees

Growth Plots ${ }^{\dagger}$

\section{Jurisdiction Dataset*}

Trees

Plot

5-year growth

\section{Total Spruce Fir}

NB

$\mathrm{NB}$

NS

PEI

Maine

$\begin{array}{lrrr}\text { DNR PSP } & 758 & 532 & 384 \\ & & & \\ \text { DNR TSP } & 3,042 & 1,617 & 1854\end{array}$

AT PSP

8

5

\author{
DNR CFI 2,177
}

1,633

1082

DNR ELC 48

423

103

FFW PSP 108

92

25

FFW CFI 409

208

163

FIA CFI 1,393 $784 \quad 61$

$5,028 \quad 2,863$

2,540

7,063

400

868

194

807

101

44

161

JDI TSP

81

45

39

795

51
624

204

2,536

4,225
645

646

647

648

649

650

651

652

653

654

655

656

657

658

* Dataset descriptions:

NB DNR PSP - NB Dep. Nat. Res. provincial permanent sample plots for tree growth research.

NB DNR TSP - NB Dep. Nat. Res. provincial co-dominant and dominant height-age trees collected in temporary sample plots for stand and forest inventory estimation.

NB AT PSP - Acadian Timber Inc. permanent sample plots in northwestern NB.

NS DNR CFI - NS Dep. Nat. Res. provincial continuous forest inventory plots.

NS DNR ELC - NS Dep. Nat. Res. ecological classification temporary sample plots.

PEI FFW PSP - PEI Dep. Forest, Fish and Wildlife permanent sample plots for tree growth research.

NS FFW CFI - PEI Dep. Forest, Fish and Wildlife continuous forest inventory plots.

Maine FIA CFI - State continuous forest inventory plots; Forest Inventory and Analysis Unit, USDA For. Serv.

Maine JDI TSP - J.D. Irving, Limited co-dominant and dominant height-age trees collected in temporary sample plots for stand and forest inventory estimation in northern Maine forests.

${ }^{\dagger}$ Growth observations were limited to after 1990 to avoid confounding effects of the last spruce budworm outbreak in the region 
Table 2. Various site predictor variable descriptions, spatial resolution, key references, and data providers used in the analysis.

\begin{tabular}{|c|c|c|c|}
\hline Predictor & Resolut & & Reference / Data Provider \\
\hline \multicolumn{4}{|c|}{ Climate } \\
\hline $\begin{array}{c}\text { Mean growing season } \\
\text { temperature normals 1971- } \\
2000\end{array}$ & $800 \mathrm{~m}$ & Yes & \multirow{3}{*}{$\begin{array}{l}\text { McKenney et al. (2006). Custom climate normal } \\
\text { predictions at } 800 \mathrm{~m} \text { resolution for the region courtesy } \\
\text { of Dr. Dan McKenney and his staff, Nat. Res. Canada. } \\
\text { Transferred in } 2014 \text {. }\end{array}$} \\
\hline $\begin{array}{c}\text { Frost free days normals } \\
1971-2000\end{array}$ & $800 \mathrm{~m}$ & Yes & \\
\hline $\begin{array}{l}\text { Other tested climate } \\
\text { normals } 1971-2000^{* \dagger}\end{array}$ & $800 \mathrm{~m}$ & No & \\
\hline $\begin{array}{l}\text { Annual mean wind speed at } \\
\qquad 30 \mathrm{~m} \text { elevation }\end{array}$ & $200 \mathrm{~m}$ & No & $\begin{array}{l}\text { Courtesy of Dr. Yves Gagnon, Wind Energy Institute } \\
\text { of Canada and PEI, NB, and NS governments; EOEEA } \\
\text { via True Wind Solutions, LLC for Maine (accessed } \\
\text { online, fall 2015) }\end{array}$ \\
\hline \multicolumn{4}{|c|}{ Lithology and soil } \\
\hline $\begin{array}{c}\text { Bedrock Index (BRI) } \\
\text { derived from rock type } \\
\text { observed regional effect on } \\
\text { site }\end{array}$ & $\begin{array}{l}\text { Sampled to } 50 \\
\mathrm{~m}\end{array}$ & Yes & $\begin{array}{l}\text { Shapefiles: Maine (2015), Keppie (2000), NBDNR } \\
\text { (2008), MacDougall et al. (1988) }\end{array}$ \\
\hline $\begin{array}{l}\text { Root Growing Space Index } \\
\text { (RGS) derived as a } \\
\text { combination of maximum } \\
\text { root depth and \% course } \\
\text { fragment }\end{array}$ & $\begin{array}{l}\text { Sampled to } 50 \\
\mathrm{~m}\end{array}$ & Yes & $\begin{array}{l}\text { Shapefiles: USDA (2015), MacDougall et al. (1988), } \\
\text { Colpitts et al. (1995), CANSIS (2014). Wetland and } \\
\text { rock outcrop enhancements using NBDNR (2015), } \\
\text { PEIFFW (2015), NSDNR (2015). }\end{array}$ \\
\hline Other tested soil attributes $* *$ & & No & \\
\hline \multicolumn{4}{|c|}{ Topography derived from digital elevation models (DEM) } \\
\hline Elevation & $20 \mathrm{~m}$ & No & \multirow{3}{*}{$\begin{array}{l}\text { DEM for PEI was based on LIDAR at } 6 \mathrm{~m} \text { resolution. } \\
\text { DEM for Maine and NS used SRTM at } 90 \mathrm{~m} \text {, and NB } \\
\text { used SRTM at } 30 \mathrm{~m} \text {. } \\
\text { DEM and DTW (Murphy et al. 2009) were provided } \\
\text { by the University of New Brunswick Forest Watershed } \\
\text { Research Center in } 2015 \text {. }\end{array}$} \\
\hline $\begin{array}{l}\text { Depth to water (DTW) } \\
\text { predicted at } 10 \text { m resolution } \\
\text { from DEM and mapped } \\
\text { water features. }\end{array}$ & $20 \mathrm{~m}$ & Yes & \\
\hline Slope in degrees & $20 \mathrm{~m}$ & Yes & \\
\hline
\end{tabular}




\begin{tabular}{cccc}
\hline $\begin{array}{c}\text { Terrain wetness, roughness, } \\
\text { and openness index }\end{array}$ & $30 \mathrm{~m}$ & No & SAGA (Böhner et al. 2006) \\
\hline & $30 \mathrm{~m}$ & No & Derived in ArcGIS using Fu and Rich (2002) \\
\hline * Dropped from final mon
\end{tabular}

$660 *$ Dropped from final model due to correlation with stronger variables or weak site influence.

$661 \dagger$ All climate normals (Table 1 in McKenney et al. 2006) were explored.

$662 \ddagger$ Other soil attributes explored where available: \% sand, \% clay, depth of organic layers, \% organic matter in mineral soil, bulk 663 density, $\mathrm{pH}$, alternate soil profile layer depth summaries, mode of deposition, and calculated soil water holding capacity using Saxton 664 and Rawls (2006). 
665 Table 3. Bedrock type groups, examples, and bedrock productivity index (BRI). Higher BRI values

666 correspond to higher site productivity.

\begin{tabular}{ccc}
\hline Bedrock type group & Examples of dominant rocks in each group & BRI \\
\hline Felsic & Granite, rhyolite & 0.00 \\
\hline Intermediate felsic & Granodiorite, mixed felsic/mafic & 0.10 \\
\hline Coarse sedimentary & Sandstone, conglomerate, gneiss, coarse meta-sedimentary & 0.25 \\
\hline Intermediate mafic & Diorite, mixed mafic/felsic & 0.50 \\
\hline Mafic & Gabbro, basalt & 0.60 \\
\hline Fine Sedimentary & Mudstone, siltstone, fine meta-sedimentary & 0.75 \\
\hline Weakly calcareous & Calcareous concentrations present in fine or course & \\
& & sedimentary \\
& & 0.85 \\
Calcareous & Limestone, dolomite, marble, strongly calcareous & \\
& &
\end{tabular}

667 
668 Table 4. Biomass growth model variables with plot data range and Random Forests importance

669 scores (RFI), and non-linear model parameter estimates for eq. 3.

\begin{tabular}{|c|c|c|c|c|c|c|c|}
\hline \multirow[t]{2}{*}{ Variable } & \multirow[t]{2}{*}{ Units } & \multicolumn{2}{|c|}{ Plot data } & \multirow{2}{*}{$\begin{array}{l}\mathbf{R F I}^{\dagger} \\
(\%)\end{array}$} & \multicolumn{3}{|c|}{ Equation 3 parameters $(P)$} \\
\hline & & Range & Mean \pm SD & & $\mathbf{P}$ & Estimate & $\mathbf{S E}$ \\
\hline Intercept & - & - & - & - & $a 0$ & -7335.78 & 327.696 \\
\hline Frost free days & Days & $81-172$ & $123 \pm 17.3$ & 3.24 & $a 1$ & 8.194 & 0.6891 \\
\hline $\begin{array}{l}\text { Mean growing } \\
\text { season temperature }\end{array}$ & ${ }^{\circ}$ Celsius & $10.9-14.6$ & $12.9 \pm 0.70$ & 14.8 & $a 2$ & 568.436 & 18.8332 \\
\hline Root growing space* & $\mathrm{cm}$ & $-1-100$ & $42.0 \pm 15.1$ & 1.17 & $a 3$ & 327.218 & 31.3813 \\
\hline Bedrock index & - & $0-1$ & $0.42 \pm 0.22$ & 4.12 & $a 4$ & 1205.979 & 56.2682 \\
\hline Depth to water & $\mathrm{cm}$ & $0-150$ & $7.10 \pm 11.3$ & 2.14 & $a 5$ & 55.823 & 6.4501 \\
\hline \multirow[t]{3}{*}{ Slope } & \multirow[t]{3}{*}{ Degrees } & \multirow[t]{3}{*}{$0-40$} & \multirow[t]{3}{*}{$3.72 \pm 4.03$} & \multirow[t]{3}{*}{3.88} & $a 6$ & 705.452 & 160.4658 \\
\hline & & & & & so & 0.594 & 0.1383 \\
\hline & & & & & sl & 0.111 & 0.0274 \\
\hline $\begin{array}{l}\text { Percentage basal area } \\
\text { Populus spp. }\end{array}$ & $\%$ & $0-100$ & $3.70 \pm 11.5$ & 4.28 & $a 7$ & 19.08 & 0.9206 \\
\hline $\begin{array}{l}\text { Percentage basal area } \\
\text { Pinus spp. }\end{array}$ & $\%$ & $0-100$ & $5.11 \pm 15.0$ & 1.06 & $a 8$ & 8.687 & 0.7799 \\
\hline Biomass & $\mathrm{tha}^{-1}$ & $1-250$ & $107 \pm 19.2$ & 88.6 & $b 0$ & 0.013 & 0.0007 \\
\hline \multirow{2}{*}{$\begin{array}{l}\text { Quadratic mean } \\
\text { diameter }\end{array}$} & \multirow[t]{2}{*}{$\mathrm{cm}$} & \multirow[t]{2}{*}{$9.5-60$} & \multirow{2}{*}{$19.2 \pm 4.58$} & 10.31 & $c 0$ & 0.145 & 0.0357 \\
\hline & & & & & $c l$ & 0.045 & 0.0035 \\
\hline
\end{tabular}

* -1 for tree bogs and marshes

$671 \dagger$ Random Forest variable importance measured as the \% increase in model mean squared error

672 resulting from random alterations in the subject variable observed values during prediction.

673 Importance value and variable rank varied by about \pm 3 each time the model was trained. 
674 Table 5. Site tree (spruce, balsam fir) index variation explained by provincial land class (LC),

675 biomass growth index (BGI; eq. 8), and combined (LC+BGI) site predictors with Random Forest;

676 best species site index model is shown in bold.

Error explained (Random Forest; out of bag $\left.\mathbf{r}^{2}\right)^{\ddagger}$

Jurisdiction Dataset* Spruce site index model Fir site index model

\begin{tabular}{|c|c|c|c|c|c|c|c|}
\hline & & \multirow{2}{*}{$\mathbf{L C}$} & \multirow{2}{*}{\multicolumn{2}{|c|}{ BGI LC+BGI }} & \multirow{2}{*}{\multicolumn{2}{|c|}{ LC BGI }} & \multirow[b]{2}{*}{$\mathbf{L C}+\mathbf{B G I}$} \\
\hline & & & & & & & \\
\hline \multirow[t]{2}{*}{$\mathrm{NB}$} & DNR PSP & 1 & 3 & -3 & 2 & 1 & - \\
\hline & $\mathrm{DNR}_{\mathrm{TSP}}{ }^{\dagger}$ & 5 & 9 & 8 & 4 & 5 & 6 \\
\hline \multirow[t]{2}{*}{ NS } & CFI & 25 & 18 & 33 & 17 & 17 & 26 \\
\hline & $\mathrm{TSP}^{\dagger}$ & 19 & 9 & 26 & 11 & 27 & 35 \\
\hline \multirow[t]{2}{*}{ PEI } & PSP & 39 & 31 & 43 & - & - & - \\
\hline & $\mathrm{CFI}^{\dagger}$ & 26 & 26 & 27 & 3 & 3 & 1 \\
\hline
\end{tabular}

$677 *$ See Table 1 for dataset description and site tree sample size.

$678 \dagger$ Dataset (locations and inventory methods) independent of data used to fit BGI model.

$679 \ddagger$ Based on observations randomly held out (out of bag) during decision tree construction to provide

680 a pseudo estimate of model performance on unseen data. ‘-‘ indicates no error explained.

681 


\section{List of Figures}

683 Fig. 1. Biomass growth rate (BG; eq. 3) predicted asymptote $\left(\mathrm{kg} \mathrm{ha}^{-1} \mathrm{yr}^{-1}\right)$ resulting from changes to 684 mean plot values (black dots) across the observed range of A) climate, B) topography, and C) soil 685 predictor variables, and D) predicted asymptote growth multiplier values across the range of plot 686 dry-biomass and quadratic mean diameter values.

687 Fig. 2. Biomass growth model (eq. 3) residual error $\left(\mathrm{kg} \mathrm{ha}^{-1} \mathrm{yr}^{-1}\right.$; plot mean observed rate minus 688 predicted rate) interpolated at $5 \mathrm{~km}$ resolution with kriging.

689 Fig. 3. Biomass growth index (BGI; $\mathrm{kg} \mathrm{ha}^{-1} \mathrm{yr}^{-1}$; eq. 8) estimated at $20 \mathrm{~m}$ resolution; i.e., asymptote 690 of the biomass annual growth model (eq. 3) with stand species composition and stand structure 691 variables held constant at zero.

692 Fig. 4. Observed average plot spruce and fir site index over biomass growth index (BGI; $\mathrm{kg} \mathrm{ha}^{-1} \mathrm{yr}^{-}$

693 ; ; eq. 8) with lowess trend lines and Random Forest $\mathrm{r}^{2}$ for each species and dataset (a-f) listed in 694 Table 5. 

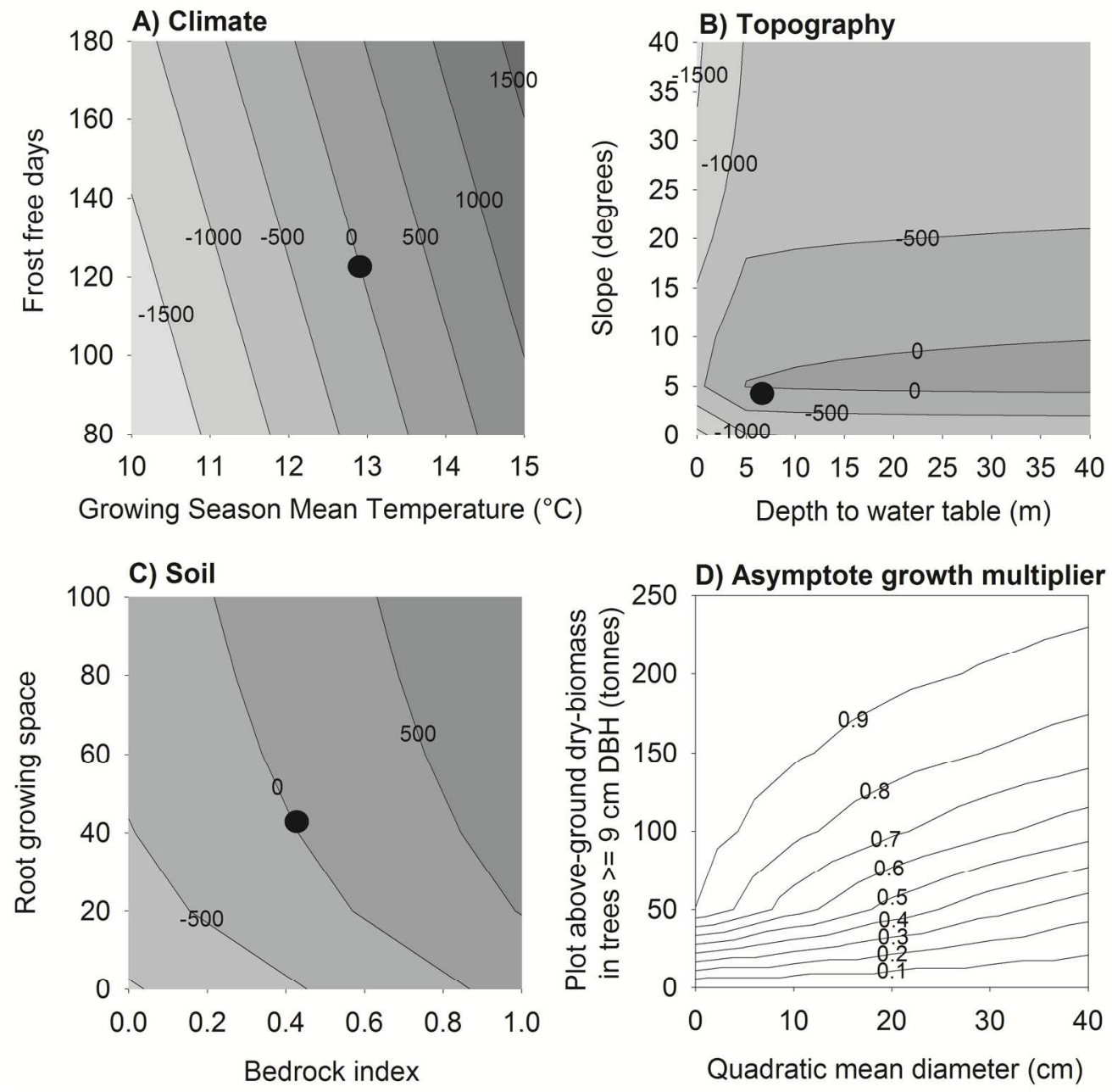

Fig. 1. Biomass growth rate (BG; eq. 3) predicted asymptote $\left(\mathrm{kg} \mathrm{ha}^{-1} \mathrm{yr}^{-1}\right)$ resulting from changes to mean plot values (black dots) across the observed range of A) climate, B) topography, and C) soil predictor variables, and $\mathrm{D}$ ) predicted asymptote growth multiplier values across the range of plot dry-biomass and quadratic mean diameter values.

Fig. 1

$172 \times 170 \mathrm{~mm}(300 \times 300 \mathrm{DPI})$ 


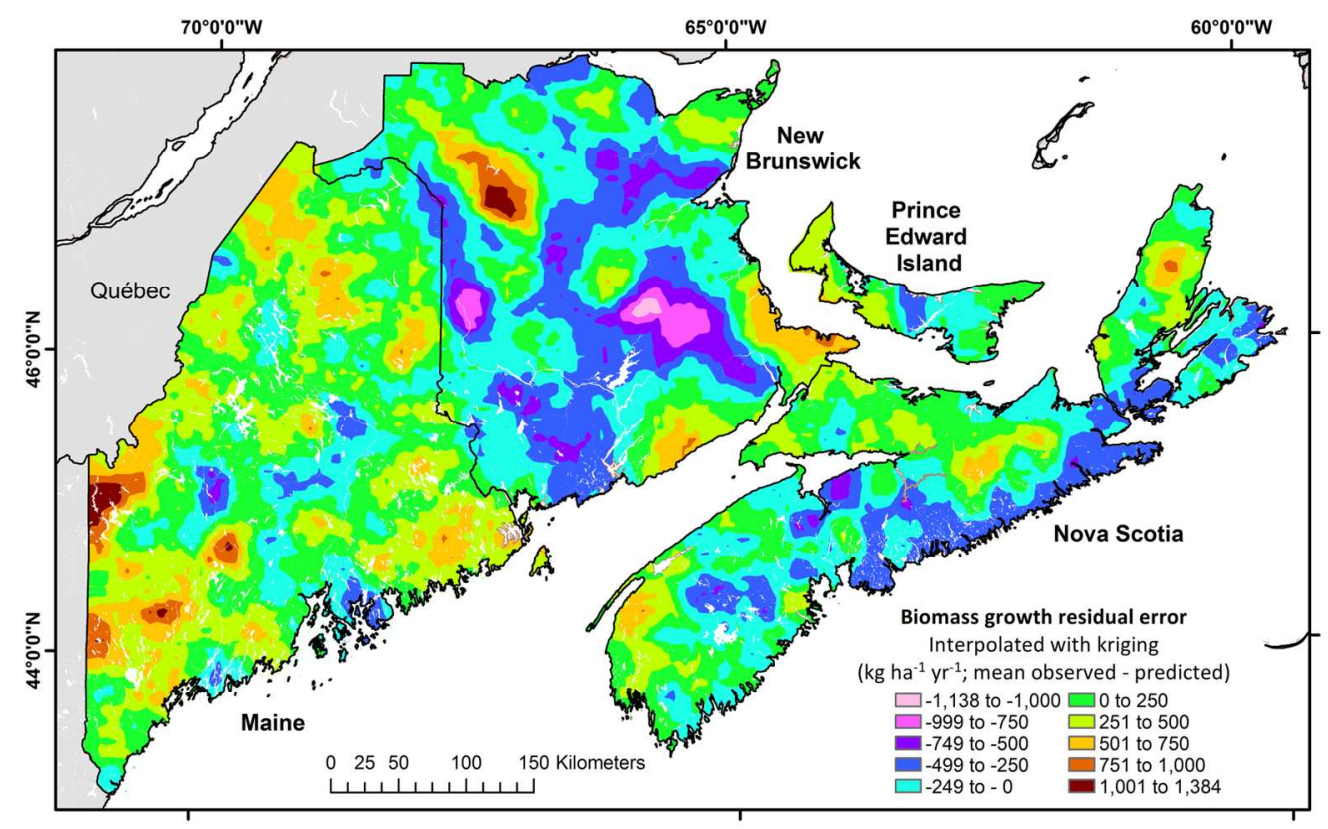

Fig. 2. Biomass growth model (eq. 3) residual error $\left(\mathrm{kg} \mathrm{ha}^{-1} \mathrm{yr}^{-1}\right.$; plot mean observed rate minus predicted rate) interpolated at $5 \mathrm{~km}$ resolution with kriging.

Fig. 2

$146 \times 90 \mathrm{~mm}(300 \times 300 \mathrm{DPI})$ 


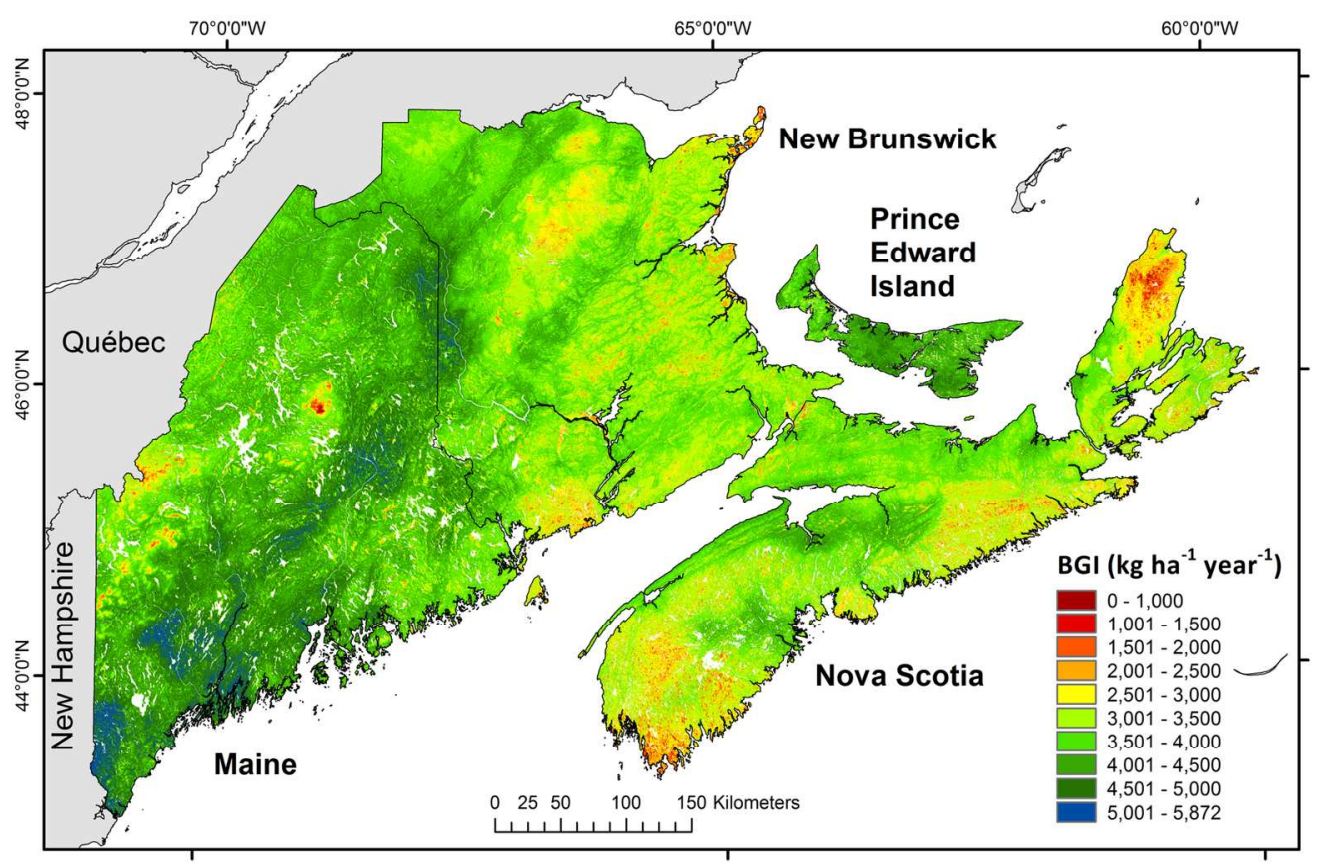

Fig. 3. Biomass growth index (BGI; $\mathrm{kg} \mathrm{ha}^{-1} \mathrm{yr}^{-1}$; eq. 8) estimated at $20 \mathrm{~m}$ resolution; i.e., asymptote of the biomass annual growth model (eq. 3) with stand species composition and stand structure variables held constant at zero.

Fig. 3

$154 \times 101 \mathrm{~mm}(300 \times 300 \mathrm{DPI})$ 

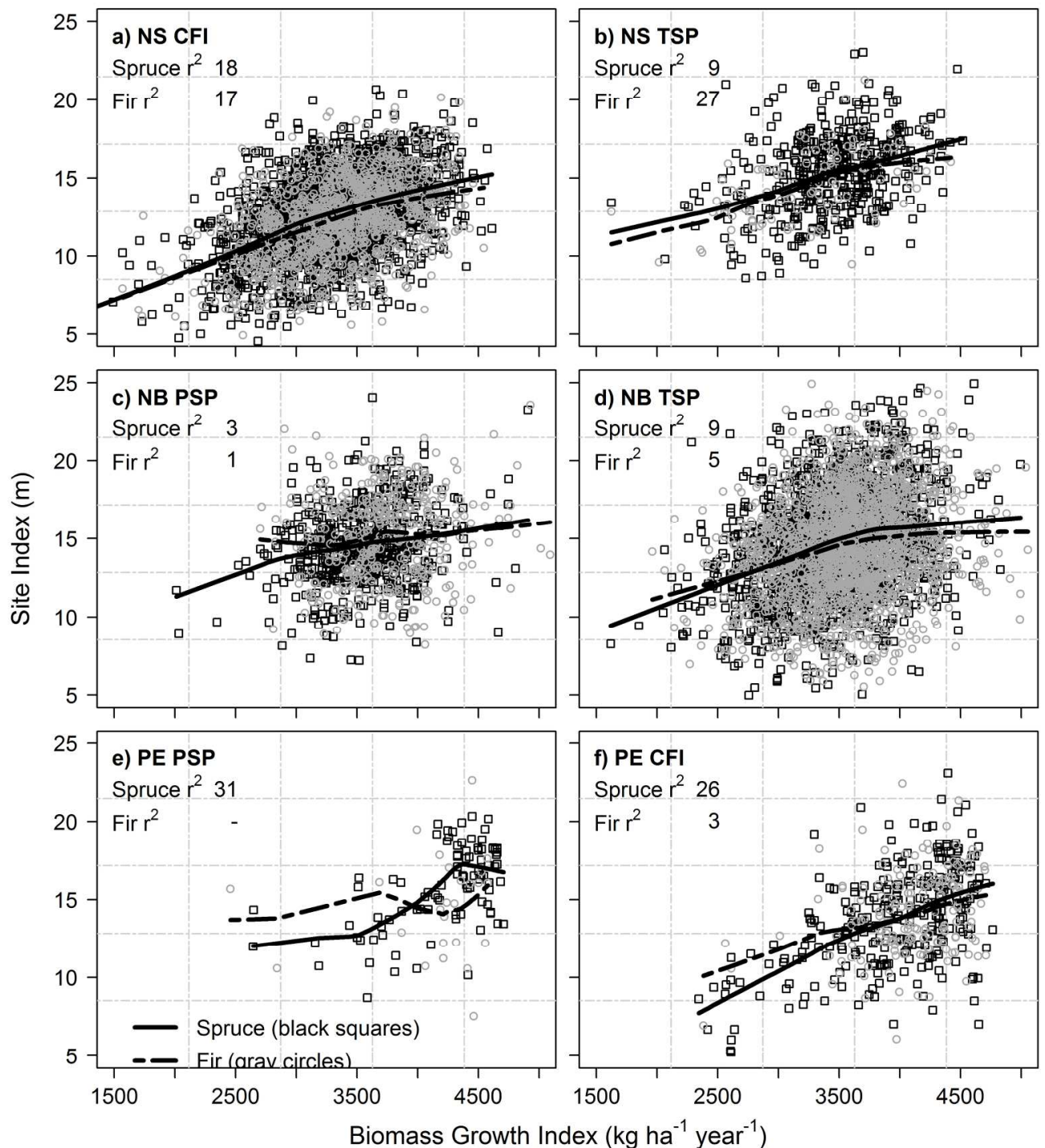

Fig. 4. Observed average plot spruce and fir site index over biomass growth index (BGI; $\mathrm{kg} \mathrm{ha}^{-1} \mathrm{yr}^{-1}$; eq. 8) with lowess trend lines and Random Forest $r^{2}$ for each species and dataset (a-f) listed in Table 5.

Fig. 4

$199 \times 222 \mathrm{~mm}(300 \times 300 \mathrm{DPI})$ 